\title{
Women Entrepreneurship in India-Problems and Prospects
}

\author{
K. Swarnalatha ${ }^{1}$, Anuradha R. K. ${ }^{2}$ \\ ${ }^{\mathbf{1}}$ Research scholar, Department of Home science, S. V. University, Tirupathi, Andhra Pradesh, India \\ ${ }^{2}$ Associate Professor, Department of Home science, S. V. University, Tirupathi, Andhra Pradesh, India
}

\begin{abstract}
Entrepreneurs play a key role in the economic development of the country. A "women entrepreneur "' is defined as the women or group of women, who initiate, organize and operate a business enterprise. Government of India has defined 'women entrepreneurs' as an enterprise owned and controlled by a woman having a minimum financial interest of 51 percent of the capital and giving at least 51 percent of employment generated in the enterprise to women. Educated Indian women have to go a long way to achieve equal rights and position because traditions are deep routed in Indian society where the sociological set up is male dominated one. Despite all the social hurdles, many Indian women stood as successful entrepreneurs. The transformation of social fabric of the Indian society, in terms of increased educational status of women and varied aspirations for better living, necessitated a change in life style of Indian women. Women in India face many problems and constraints to get ahead in their life in business. They should explore the prospects of starting new enterprise; undertake risks, introduce innovations, coordinate administration and control business and provide effective leadership in all aspects of business. The present paper endeavors to study problems of women entrepreneurs, how to develop women entrepreneurs and study schemes for women operated by different departments and ministries.
\end{abstract}

Keywords: Women Entrepreneurs, Enterprise, Problems, Education, Initiatives

\section{Introduction}

Entrepreneurship is the purposeful activity of an individual or a group of associated individuals, undertaken to initiate, maintain or organize a profit oriented business unit for the production or distribution of economic goods and services. In India, gender discrimination is high. Owing to various socio-cultural reasons women are prohibited to enter into the entrepreneurial world. Entrepreneurship is one such a field where women's participation is very low, although there is lot of improvements in women literacy rate. In 1971, the women constituted only $2 \%$ of total entrepreneurs. Now it has increased nearly $10 \%$ in the present modern world. Women entrepreneurs are recognized as powerful instruments for the economic development of any nation as well as the catalyst in bringing the changes in the society.The educated women do not want to limit their lives in the four walls of the house. They demand equal respect from their partners. However, Indian women have to go a long way to achieve equal rights and position because traditions are deep rooted in Indian society where the sociological set up has been a male dominated one. Women are considered as weaker sex and always made to depend on men folk in their family and outside, throughout their life. But there are some women leaders who take leadership role in empowerment of women. These women leaders are assertive, persuasive and willing to take risks. They managed to survive and succeed in this cut throat competition with their hard work, diligence and perseverance. Ability to learn quickly from her abilities, her persuasiveness, open style of problem solving, willingness to take risks and chances, ability to motivate people, knowing how to win and lose gracefully are the strengths of the Indian women entrepreneurs.

Under the influence of these factors the women entrepreneurs choose a profession as a challenge and as an urge to do something new. Such a situation is described as pull factors. While in push factors women engaged in business activities due to family compulsion and the responsibility is thrust upon them.

\section{Problems of Women Entrepreneurs}

There are many problems faced by women Entrepreneurs. Some of them are

1) Patriarchal Society: Entrepreneurship has been traditionally seen a male preserve and idea of women taking up entrepreneurial activities considered as a distant dream. Women also have to face role conflict as soon as they initiate any entrepreneurial activity

2) Absence of Entrepreneurial Aptitude: Many women take the training by attending the Entrepreneurship Development Programmes without entrepreneurial bent of mind. As per a study, involvement of women in small scale sector as owners stands at mere 7 percent.

3) Quality of EDPs: All women entrepreneurs are given the same training through EDPs. Second-generation women entrepreneurs don't need such training as they already have the previous exposure to business

4) Marketing Problems: Women entrepreneurs continuously face the problems in marketing their products. It is one of the core problems as this area is mainly dominated by males and even women with adequate experience fail to make a dent. For marketing the products women entrepreneurs have to be at the mercy of middlemen who pocket the chunk of profit and also find it difficult to capture the market and make their products popular.

5) Financial Problems: Obtaining the support of bankers, managing the working capital, lack of credit resources are the problems which still remain in the males domain. Marketing and financial problems are such obstacles where even training doesn't significantly help 


\section{International Journal of Science and Research (IJSR) \\ ISSN (Online): 2319-7064 \\ Index Copernicus Value (2013): 6.14 | Impact Factor (2014): 5.611}

the women. Some problems are structural in nature and beyond the control of entrepreneurs.

6) Family Conflicts: Women also face the conflict of performing of home role as they are not available to spend enough time with their families. They spend long hours in business and as a result, they find it difficult to meet the demands of their family members and society as well. Their inability to attend to domestic work, time for education of children, personal hobbies, and entertainment adds to their conflicts.

7) Credit Facilities: Though women constitute about 50 per cent of population, the percentage of small scale enterprise where women own 51\% of share capital is less than 5 percent. Women are often denied credit by bankers on the ground of lack of collateral security. At the same time, a good deal of self- employment programme has been promoted by the Govt. and commercial banks.

8) Shortage of raw-materials: Women entrepreneurs encounter the problem of shortage of raw-materials. This problem is because of the inadequate availability of raw materials.

9) Heavy Competition: Many of the women enterprises have imperfect organizational set up. But they have to face severe competition from organized industries.

10) High cost of production: High cost of production undermines the efficiency and stands in the way of development and expansion of women's enterprises, government assistance in the form of grant and subsidies to some extent enables them to tide over the difficult situations. However, in the long run, it would be necessary to increase efficiency and expand productive capacity and thereby reduce cost to make their ultimate survival possible, other than these, women entrepreneurs so face the problems of labour, human resources, infrastructure, legal formalities, overload of work, lack of family support, mistrust etc.

\section{Suggestions for the Growth of Women Entrepreneurs}

The following measures are suggested to empower the women to seize various opportunities and face challenges in business:

- There should be a continuous attempt to inspire, encourage, motivate and co-operate women entrepreneurs. An Awareness programme should be conducted on a mass scale to create awareness among women about the various areas to conduct business.

- Attempts should be there to enhance the standards of education of women in general as well making effective provisions for their training, practical experience and personality development programmes, to improvise their over-all personality standards.

- Organize training programmes to develop professional competencies in managerial, leadership, marketing, financial, production, profit planning, maintaining books of accounts and other skills.

- Vocational training to be extended to women community that enables them to understand the production process and production management.
- Skill development to be done in women's polytechnics and Industrial Training Institutes. Skills are put to work in training-cum-production workshops.

- Educational Institutes should tie up with various government and non-government agencies to assist in entrepreneurship development mainly to plan business projects.

- International, National, Local trade fairs, Industrial exhibitions, seminars and conferences should be organized to help women to facilitate interaction with other women entrepreneurs.

- Women in business should be offered soft loans \& subsides for encouraging them into industrial activities. The financial institutions should provide more working capital assistance both for small scale venture and large scale ventures.

- Making provision of micro credit system and enterprise credit system to the women entrepreneurs at local level.

The weaker section could raise funds through various schemes and incentives provided by the government to develop entrepreneurs in the state. E.g. the PMRY, KVIC etc. To establish All India Forums to discuss the problems, grievances, issues, and filing complaints against constraints or shortcomings towards the economic progress path of women entrepreneurs and giving suitable decisions in the favor of women entrepreneurs and taking strict stand against the policies or strategies that obstruct the path of economic development of such group of women entrepreneurs.

\section{Steps Taken by the Government}

Development of women has been a policy objective of the government since independence. Women were given priorities in all the sectors including SSI sector. Government and Non-Government bodies have paid increasing attention to women's economic contribution through self-employment and industrial ventures.

- The First Five-Year Plan (1951-56) envisaged a number of welfare measures for women. Establishment of the Central Social Welfare Board, organization of Mahila Mandal etc.

- The Second Five-Year Plan (1956-61) Empowerment of women was closely linked with the overall approach of Intensive Agricultural Development Programmes(IADP).

- The Third and Fourth Five-Year Plans (1961-66 and 1969-74) supported female education as a major welfare measure.

- The Fifth Five-Year Plan (1974-79) emphasized training of women, in need of income and protection. This plan coincided with International Women's Decade and the submission of Report of the Committee on the Status of Women in India. In1976, Women's welfare and Development Bureau was set up under the Ministry of Social Welfare.

- The Sixth Five-Year Plan (1980-85) saw a definite shift from welfare to development. It recognized women's lack of access to resources as a critical factor impending their growth.

- The Seventh Five-Year Plan (1985-90) emphasized the need for gender equality and empowerment. Emphasis 


\section{International Journal of Science and Research (IJSR) \\ ISSN (Online): 2319-7064 \\ Index Copernicus Value (2013): 6.14 | Impact Factor (2014): 5.611}

was placed upon qualitative aspects such as inculcation of confidence, generation of awareness with regards to rights and training in skills

- The Eight Five-Year Plan (1992-97) focused on empowering women, especially at the Gross Roots Level, through Panchayat Raj Institutions.

- The Ninth Five-Year Plan (1997-2002) adopted a strategy of Women's Component Plan, under which not less than 30 percent of funds/ benefits were earmarked for women related sectors.

- The Tenth Five-Year Plan (2002-07) aims at empowering women through translating the recently adopted National Policy for Empowerment of Women (2001) into action and ensuring Survival, Protection and Development of women and children through rights based approach.

At present, the Government of India has over $\mathbf{2 7}$ schemes for women operated by different Departments and Ministries.

They are

- Integrated Rural Development Programme (IRDP)

- Khadi and Village Industries Commission (KVIC)

- Training of Rural Youth for Self-Employment (TRYSEM)

- Prime Minister's Rojgar Yojana (PMRY)

- Entrepreneurial Development programme (EDPs)

- Management Development programmes

- Women's Development Corporations (WDCs)

- Marketing of Non-Farm Products of Rural Women (MAHIMA)

- Assistance to Rural Women in Non-Farm Development (ARWIND) schemes

- Trade Related Entrepreneurship Assistance and Development (TREAD)

- Working Women's Forum

- Indira Mahila Yojana

- Indira Mahila Kendra

- Mahila SamitiYojana

- Mahila Vikas Nidhi

- Micro Credit Scheme

- Rashtriya Mahila Kosh

- SIDBI‘s Mahila Udyam Nidhi

- Mahila Vikas Nidhi

- SBI's Stree Shakti Scheme

- NGO's Credit Schemes

- Micro \& Small Enterprises Cluster Development Programmes (MSE-CDP).

- National Banks for Agriculture and Rural Development‘s Schemes

- Rajiv Gandhi Mahila Vikas Pariyojana (RGMVP)

- Priyadarshini Project

- NABARD-SEWA Bank Project.

\section{Conclusions}

An entrepreneur is one who plays significant role in the economic development of a country. The most important challenges faced by new entrepreneurs include Developing the Vision and Business Idea, Raising Capital for Startup, Assembling a Business Team, Finding the Right Business Location, Finding Good Employees, Finding Good Customers, Dealing with competition, Unforeseen Business
Challenges and Expenses, lack of support, negative mindset, lack of marketing facilities, lack of infrastructural facilities etc. So it is necessary to overcome these challenges in order to conduct an efficient business. Women should try to upgrade themselves in the changing times by adapting the latest technology benefits. Women must be educated and trained constantly to acquire the skills and knowledge in all the functional areas of business management. Self-help groups of women entrepreneurs to mobilize resources and pooling capital funds, in order to help the women in the field of industry, trade and commerce can also play a positive role to solve this problem.

\section{References}

[1] Baumol, W.J. 1993. Formal Entrepreneurship Theory in Economics.

[2] Entrepreneurship Development, Himalaya Publications.

[3] Padmanand, V., and Patel, V.G. 2004. Managing India s Small Industrial Economy. New Delhi Sage Publications

[4] Saini, J.S., and Gurjar, B.R.2001. Entrepreneurship and Education, Challenges and strategies

[5] Women Entrepreneurs in India- a socioeconomic study of Delhi-1075, Mittal publications, Delhi

[6] Siva Loganathan.k:' Women Entrepreneurs: Problems and Prospects, Indian Economic Panorama,12(2),2002. 